\title{
PROPOSAL AND APPLICATION OF A PROCEDURE FOR ANALYSIS OF IDLENESS AND WASTES IN AN AIRCRAFT COMPANY
}

\author{
PROPOSTA E APLICAÇÃO DE UM PROCEDIMENTO PARA ANÁLISE DA POROSIDADE E DE DESPERDIICIOS EM UMA \\ EMPRESA DE AERONAVES
}

Luiz Carvalho Neto ${ }^{1}$

Fabiano Leal ${ }^{2}$

Milena Silva de Oliveira ${ }^{3}$
${ }^{1}$ Mestre em Engenharia de Produção Universidade Federal de Itajubá Itajubá/MG, Brasil luiz.carvalho.neto@hotmail.com

${ }^{2}$ Doutor em Engenharia de Produção Universidade Federal de Itajubá Itajubá/MG, Brasil fleal@unifei.edu.br

${ }^{3}$ Mestre em Engenharia de Produção Universidade Federal de Itajubá Itajubá/MG, Brasil mile_4689@hotmail.com

\begin{abstract}
This study analyses workmen's performance in an aeronautical manufacture. Idleness, defined as waste concerning counterproductive work behaviors (CWBs), and added value taxes will be analyzed by testing four propositions: differences among collecting data techniques; differences among wastes; variation of added value rates along the working day and workmen's profiles having the biggest impacts on idleness. Data gathered from Integrated Management System were higher than the observed, the idleness presented the biggest value among other wastes, morning had bigger added value than afternoon (especially end of the morning) and workmen who are married and have children had smaller idleness. This article shows how the idleness can perform an important role in Lean analyses in operations management and how the procedure can guide strategies to decrease the idleness.
\end{abstract}

Keywords: Circadian rhythm. Counterproductive work behavior. Idleness. Lean manufacturing. Loafing.

\section{Resumo}

Este estudo analisa o desempenho dos trabalhadores em uma empresa aeronáutica. Porosidade (ociosidade) foi definida como desperdícios referentes a comportamentos contraproducentes no trabalho, e a taxa de agregação de valor será analisada testando quatro hipóteses: diferenças entre técnicas de coleta de dados; diferenças entre os tipos de desperdícios medidos; variação da taxa de agregação de valor durante o dia de trabalho e relação entre ociosidade e informações sobre o perfil do operador. Os dados coletados do Sistema de Gestão Integrada (SGI) da empresa foram superiores aos observados, a ociosidade apresentou o maior valor dentre outros desperdícios, a parte da manhã teve maior valor agregado do que a parte da tarde (especialmente no final da manhã) e os trabalhadores que eram casados e tinham filhos apresentaram menor ociosidade. Este artigo mostra como a ociosidade é importante nas análises Lean no gerenciamento de operações e como o procedimento pode diminuir a ociosidade.

Palavras-chave: Ritmo circadiano. Comportamentos contraproducentes no trabalho. Porosidade. Produção enxuta. Preguiça social. 


\section{Introduction}

According to Jasti and Kodali (2014), only 3.37\% of empirical researches on Lean Manufacturing use data from aerospace sector. Although several definitions of Lean contain the concept of elimination of wastes (Bhamu \& Sangwan, 2014), the elimination of wastes is mentioned in only $2.5 \%$ of Lean articles whereas Kanban is the element / tool / technique more mentioned (Jasti \& Kodali, 2014). Actually, there is a lack of empirical researches on Lean in aerospace sector with focus on elimination of wastes.

This paper will measure and analyze added value rates and wastes, especially the idleness, performed by workmen in an aeronautical manufacturer. Idleness will be defined as a kind of waste concerning counterproductive work behaviors. Spector and Fox (2010) define CWB as intentional behaviors intended to harm the organization or its members. CWBs can interfere on performance of work and costs (Whelpley \& McDaniel, 2016). A systematic literature review was performed and found no articles merging Lean Manufacturing and CWB as a potential kind of wastes.

According to Roth (2007), one of the major tasks of operational management is developing, exploring, and testing theories about phenomena of interest to operations managers. In this context, this case-study paper has as goals testing 4 propositions to analyze added value rates and the idleness: the first about differences among collecting data techniques; the second about differences among types of wastes; the third about variation of added value rates along the working day and the fourth about workmen's profiles that have the biggest impacts on idleness. The item 3.1 shows more details about the proposition will be test. These results and analyses can be used by the company to guide actions and operational management strategies to increase value added taxes. The main contribution of this paper for the literature is the discussion about the idleness as a major waste in Lean Manufacturing environment in the analyzed study object. This paper also offers a framework for replicates.

\section{Theoretical background}

\subsection{Lean manufacturing and wastes}

According to Samuel, Found and Williams (2015), the term Lean Manufacturing was first used by Krafcik in 1988 to describe the successful Toyota production system and became popular with the publication of the book The Machine That Changed the World by Womack, Jones and Roos in 1990. Lean can be defined as a management philosophy focused on identifying and eliminating waste through the entire value stream of a product (Shah \& Ward, 2007). However, Bhamu and Sangwan (2014) affirm, after analyzing 209 articles, that there is an absence of a common definition of Lean Manufacturing. They listed the found definitions, its scope of action and its goals. 
Womack and Jones (2003) define value as the ability to provide a customer at the right time and at an appropriate price as defined by the customer. They claim that value can only be set by the end customer. Haque and Moore (2004) state that Lean has a single strategic goal of eliminating waste and improving the flow of value, that is, increasing value added taxes. Womack and Jones (2003) also define mudas as waste. Muda is any activity that consumes resources, but does not create value and can be classified into two types: the inevitable and the one that can be completely eliminated. Ohno (1988) states that wastes can represent between $80 \%$ to $95 \%$ of time in a productive process. Womack and Jones (2003), Hines et al. (1998), Ohno (1988) and Shingo and Dillon (1989) give the examples of the seven wastes: Overproduction; Waiting; Transportation; Processing; Stock; Motion; Defect.

\subsection{Counterproductive work behavior}

Counterproductive work behavior (CWB) can be defined as voluntary behavior that violates significant organizational norms and in so doing threatens the well-being of an organization and / or its members (Robinson \& Bennett, 1995). CWB has been studied under a variety of theoretical perspectives such as aggression, deviance (behavioral), retaliation, and revenge. However, all perspectives have in common that these behaviors are volitional (as opposed to accidental or mandatory behaviors) and hurt organizations and / or involved parties of organizations, such as clients, co-workers and supervisors (Fox, Spector, Goh, Bruursema \& Kessler, 2012). CWBs are usually classified according to the purpose of their acts: against the organization or against people (Bennett \& Robinson, 2000; Robinson \& Bennett, 1995).

Some examples of acts of the CWB can be cited as: wasting time and company materials, trying to look busy doing nothing, daydreaming instead of working, purposely doing the job incorrectly (Spector, 1975); being paid for hours that have not been worked, spending a long time for lunch or coffee without the superior's approval (Hollinger, 1986); intentionally working slowly, talking with coworkers rather than work, hiding in a back room to read the newspaper, taking excessive breaks at work, coming in late or leaving early, making personal calls or mailing, lying about hours worked (Robinson \& Bennett, 1995); taking company materials without permission, trying to look busy while wasting time, spending time on personal matters at work (Skarlicki \& Folger, 1997); purposely not working steadily when there are things to be done, purposefully getting to work or coming back from pauses late, complaining about insignificant things at work, calling sick when not, try to fool the employer (Fox \& Spector, 1999); acts of thefts, fraud, vandalism, sabotage, and voluntary absenteeism (Bennett \& Robinson, 2000)

Taylor (2013), in a considerable part of his classical book Principles for Scientific Management, explains what he observed: workers performed their work more slowly than they could. Taylor called this practice of loafing, soldiering and laziness of man. From the definition and examples of Robinson 
and Bennett (1995), what Taylor observed at the beginnings of 20th century can be considered an example of CWB.

\subsection{Idleness}

Idleness is the term that will be used to designate volitional waste activities concerning workman's deviant behavior, also called by some author as CWB. It occurs when a workman does not perform added value activities when there are available resources and conditions to do them. The idleness is caused by the workman's free will.

We performed a systematic search on Scopus and ScienceDirect, using combinations of Lean ("Lean manufacturing", "Lean production", "Toyota production system", "Lean thinking", "Lean principle", "Lean management", "Lean enterprise", "Lean process", "Lean practice", "Lean approach", "Toyota way", "Lean philosophy", "Lean methodology", "Lean transformation", "Lean healthcare", "Lean health care", "Lean method", "Lean service", "Lean theory", "Lean intervention") and CWB ("Counterproductive work", "Deviant behavior", "Deviant behavior", Loafing, CWB, "Counterproductive work behavior", "Counterproductive work behavior", Cyberloafing) in article's title, abstract, or keywords. Only one article was found: Desirée, Hicks and Wilderom (2017) analyzed lean managers' values and behaviors. According to them, some lean managers can develop a deviant behavior

\section{Methodology}

Given the aim to be replicable in order to future results comparisons, the steps used in this research were carefully described. The Figure 1 shows the used framework: it was elaborated taking into account the recommendations of Voss, Tsikriktsis and Frohlich (2002) for a case research in operations management. 
Figure 1 - Framework

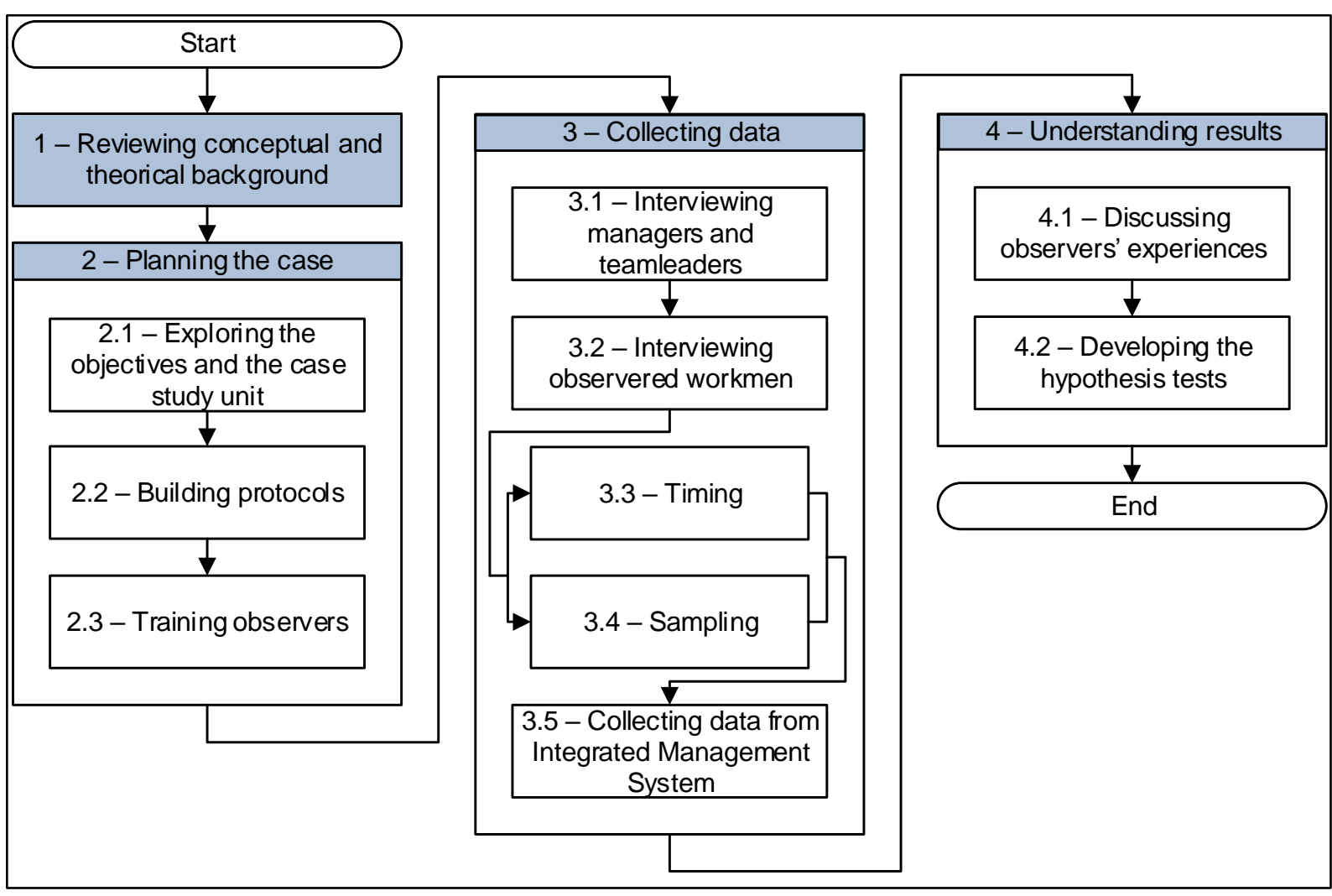

Source: Voss et al. (2002).

\subsection{Exploring the objectives and the case study unit}

This step (2.1 on Figure 1) was used to planning and preparing the research. The purpose of this article is analyzing the added value and idleness taxes trough fourth propositions that will be tested.

According to the definitions found by Bhamu and Sangwan (2014), the concept of added value and wastes play a basic role for the implementation of Lean. Shingo and Dillon (1989) stated in their book the existence of wastes that are not noticed because they have become accepted as a natural part of daily work. The first hypothesis will test how similar are the values obtained for added value from each measurement technique used (interview, timing, sampling and data from the integrated management system - IMS). The values concern the proportion between the time spent on added value activities and the available time. If the null hypothesis is rejected, the difference among results can be seen as an evidence of hiding and acceptance of wastes by certain company's departments. Thus, the first hypothesis can be seen as a verification of Shingo and Dillon (1989) statement can be made also in this case study.

P1. The median of the data collected from different measurement techniques for the added value rate can be considered equal. 
According to Jasti and Kodali (2014), the most mentioned wastes in Lean empirical articles and their frequency distribution are: stocks (59.9\%), waiting (52.7\%), defects (41.6\%), transportation (29.2\%), motion (27.5\%), processing (21.3\%), and overproduction (20.8\%). They also showed which wastes were more expected to be removed by applying Lean according to respondents from Indian industries: stock, defects, processing, waiting, motion, overproduction and transportation respectively (Jasti \& Kodali, 2016). The second proposition will test whether the values of each kind of wastes found in this case study (values for waiting, motion, defects, processing, transportation and idleness) can be considered equal one another in terms of median. The values, obtained from the timing method, concern the proportion between the time spent on each kind of wastes and the available time for the 24 observed working days. In case of rejection of null hypothesis, the hierarchy of the biggest waste means will be tested to be comparing with the lists of wastes showed by Jasti and Kodali $(2014,2016)$ as more cited wastes or wastes more expected to be removed.

P2. The median of each kind of wastes can be considered equal.

The third proposition concerns the variation of added value rate along the working day. Spencer (1987) and Grandjean and Kroemer (1997) studied the work performance along the day through circadian rhythm. Martinez-Nicolas, Madrid and Rol (2014) define circadian rhythm, 24h rhythm or circadian clock as an external manifestation of internal clocks that measure the period of the day. According to them, the circadian rhythm influences systems of immunization, secretion of hormones and energy demand. Bollinger et al. (2011) argue that modern societies can create a mismatch with the circadian system. This mismatch is related to several human pathologies, such as cancer.

Spencer (1987) analyzed the influence of sleep on the performance of airline workers. Although with a low fit, Spencer proposed a regression to determine the performance value considering the time of day and the time since wake up. Performance was measured from the results of a test called DSST.

Grandjean and Kroemer (1997) showed the influence of the circadian rhythm on what they called readiness for work that concerns a biological and subjective capacity of high performance. They cited some researches (about flight controllers, truck drivers and a gas plant in Sweden) and showed that the sleep and also feeding habits affect the readiness for work. The feeding causes an overload of the digestive organs, what is responsible for decrease the readiness for work. They proposed a theoretical variation of the readiness for work during a continuous working day with intermediary pauses.

The third proposition will admit if the added value rate can be considered constant along the workday. The values, obtained from the sampling method, concern the proportion between the 
number of workmen observed performing added values activities and the total number of observed workmen for each time when the sampling took place. In case of rejection of null hypothesis, can the added value rate variation be considered similar to the variation of performance proposed by Spencer (1987) or to the variation of readinnes for work proposed by Grandjean and Kroemer (1997)?

P3. The added value rates are constant along the day.

Fox et al. (2012) state that several studies have shown CWB correlations with potential antecedents, such as sense of justice, job satisfaction and interpersonal conflict. According to Broeck et al. (2014) job insecurity tends to increase CWB. This test will verify whether there is/are items measured in the interview that influence to a greater or smaller idleness. The items concern workmen's age, experience in the company, marital status, a specific training offered by the company, children and national state of origin. These items are used to build a workmen's profile to guide projects and management strategies, and they are expected to be influential according to some managers at the company.

P4. There is a defined workmen's profile that impact the idleness the most.

Analyses will be made in an aeronautical assembly line of a large international company located in Brazil. The assembly line has low production volume and high customization, predominantly manual works, high cycle times, high variability of tasks, a complex value flow, a high workload and workmen with highly specialized training and with much autonomy. Common techniques to analyze added value, such Value Stream Mapping, could not provide enough and detailed information for idleness and added value rates performed by workmen.

The working day began at 7:30 am and ended at 5:45 pm, with 15 minutes for break for coffee in the morning, 15 minutes in the afternoon and 1 hour for lunch. Thus, there were 8.7 available hours for work per day.

\subsection{Building protocols}

The building protocols step happened by reviewing literature, analyzing company's historical data, interviewing managers and team leaders and performing a tryout of 10 working days. The following protocols were created:

1. List of activities: a list containing all the activities that workmen could perform during a working day. Each activity was given a possible classification or a list of possible classifications according to the classification used by Tyagi, Choudhary, Cai and Yang (2015), 
who classified tasks performed in Product Development Process into 3 categories: added value (VA), necessary but non value add (NNVA), and wastes. There is also a list of possible classifications for each type of wastes. Inventory and overproduction wastes could not be measured. Defects wastes were measured as rework. The idleness was measured. Each activity also received a classification called "classification according to the company": managers asked that long-term countermeasure wastes should be considered as NNAN.

2. Timing sheet: a table where the timing information could be written by the observer during the timing of one workman at a time. This sheet considers what a workman did during his working day according to the list of activities. The length of each activity was measured with a chronometer;

3. Sampling sheet: a table where the observations of the sampling could be written by the observer. Every ten minutes the observer counted (and wrote on this sheet) how many workmen within his/her field of vision were performing AV activities; NNAN and waste (according to company classification). Sampling occurred simultaneously with timing.

4. Workmen's Profile Sheet: a sheet where the structured interview responses could be written by the observer. The interview questions were: age (in years); How long the workman was in the company (in months) - level experience; Affective situation: stable / married or single / widower / divorced; Training: whether workman attended a training abroad supported by the company or not; Children: if the workman had at least one child or did not have one; Origin: if the workman came from another Brazilian state or the state where the company is located in.

\subsection{Training observers}

The training lasted two working weeks. Four steps were followed:

1. Building the team: A team of six engineering students (undergraduates) who were not company employees was allocated to be the observer team. Training was carried out on the company, assemblies, tools, toolings, on this research, its protocols and on how decrease interference on workmen. This phase of the training lasted 30 hours;

2. Performing the tryout: Each pair of observers collected data from one workman. One observer worked (alone) in the morning while the other worked (alone) in the afternoon. The choice of workman and observers was made randomly (drawing). In total 4 working days were measured, a total of approximately 35 hours;

3. Debriefing: On the day following the end of the tryout, there was a critical analysis to clarify doubts and difficulties found by observers, and 
4. Validating observers: A one-way ANOVA hypothesis test was performed to compare AV averages of the results obtained with each observer. With a P-value of 0.355 , it cannot be concluded that there are differences between means at a significance level of $5 \%$. Therefore, it was considered that observers measure similarly to each other.

\subsection{Collecting data}

Five different measurement techniques for collecting data were used:

1. Interviewing managers and team leaders: This was chronologically the first data collecting. After explaining what AV, NNAN and waste activities would be, team leaders and managers were interviewed with the following question: what percentage of the working day, in your opinion, do the workmen spend to perform each of these three types of activities? The distinction between "NNAN" and "Waste" follows the company criteria. 11 people that worked with that assembly line were interviewed.

2. Interviewing observed workmen: the interview was made by the observer at the beginning of each working day (at the beginning of the timing and sampling). At that moment, the observer identified himself/ herself to the workman, explained how the measurements would occur and asked him whether there was any doubt.

3. Timing: It occurred similar to the tryout. Twenty-four working days / workmen were observed.

4. Sampling: Sampling occurred simultaneously with timing.

5. Collecting data from Integrated Management System (IMS): At the end of the working day, each workman inserted on the IMS (software) how much time he spent in his activities during the day. Each activity was classified automatically by the system into two types: productive or administrative. Workmen had an annual goal of having at least $90 \%$ of the time designated as productive hours. The day after the timing, information was collected by the observer team. Activities were reclassified into AV, NNAN and waste.

In total, there were 24 observed working days that was taken into account for results, 10 observed working days for building the protocols and 12 workings days for performing the tryout for training observers. All employees who worked in that assembly line and were not in vacation had their working days observed. 
4 Data analysis and discussion of results

4.1 Discussing observers' experiences

At the end of measurements, observers were given a sheet to write comments about what they observed. After writing, they presented to one another what was written and experienced. The following are some comments about the idleness:

A) Workmen talk a lot with each other about everything, especially soccer;

B) Workmen use their mobiles a lot, to look for music, to see what time it was, to talk among them, to play, etc;

C) The workman had to put his head and arms into a cavity to perform an activity. Inside the cavity nobody saw him, but me. When I got closer, I saw he was using his mobile hidden inside the cavity;

D) In an assembly, the workman was lying down under the aircraft. He did several movements with his hands, but his eyes remained closed and his mouth opened all the time;

E) Workman decided to go outside to smoke;

F) The workmen leave their workstation about half an hour before the end of the working day, especially on Fridays;

G) Workman was reading a document for a long time: he was apparently studying or reading the document. But due to the speed he turned the page and how long it took, it was impossible to read anything;

I) Some workmen said, "I do not want to work here," "I hate this city". At the same time, others said, "I resigned at company X to be here," "my dream has always been working here";

This observations show that idleness activities were mainly performed in a hidden perspective, managers couldn't easily realize it.

\subsection{Differences among collecting data techniques}

The Table 1 shows the added values found in each measurement technique. The values of timing and IMS are referent to the same workman (paired data). All samples can be considered normal, except the values from IMS. Each value of sampling corresponds to a mean of 62 observations made per working day (lunch period was not considered). 
Table 1 - Added value rates according to each measurement technique

\begin{tabular}{|c|c|c|c|c|}
\hline Working day & Timing & Sampling & Interview & IMS \\
\hline 1 & $21.0 \%$ & $26.3 \%$ & $60.0 \%$ & $34.8 \%$ \\
\hline 2 & $48.1 \%$ & $29.6 \%$ & $50.0 \%$ & $100.0 \%$ \\
\hline 3 & $38.1 \%$ & $27.5 \%$ & $60.0 \%$ & $100.0 \%$ \\
\hline 4 & $57.6 \%$ & $26.4 \%$ & $55.0 \%$ & $97.1 \%$ \\
\hline 5 & $18.1 \%$ & $33.7 \%$ & $70.0 \%$ & $99.3 \%$ \\
\hline 6 & $30.0 \%$ & $31.6 \%$ & $50.0 \%$ & $98.1 \%$ \\
\hline 7 & $30.6 \%$ & $37.2 \%$ & $30.0 \%$ & $90.0 \%$ \\
\hline 8 & $2.8 \%$ & $47.3 \%$ & $60.0 \%$ & $58.6 \%$ \\
\hline 9 & $32.3 \%$ & $36.4 \%$ & $40.0 \%$ & $86.1 \%$ \\
\hline 10 & $25.9 \%$ & $31.2 \%$ & $40.0 \%$ & $100.0 \%$ \\
\hline 11 & $0.0 \%$ & $38.3 \%$ & $55.0 \%$ & $29.4 \%$ \\
\hline 12 & $15.8 \%$ & $36.4 \%$ & & $97.6 \%$ \\
\hline 13 & $29.2 \%$ & $40.2 \%$ & & $99.7 \%$ \\
\hline 14 & $31.6 \%$ & $40.3 \%$ & & $88.5 \%$ \\
\hline 15 & $58.0 \%$ & $27.6 \%$ & & $100.0 \%$ \\
\hline 16 & $45.3 \%$ & $25.5 \%$ & & $100.0 \%$ \\
\hline 17 & $32.4 \%$ & $34.7 \%$ & & $99.3 \%$ \\
\hline 18 & $31.4 \%$ & $45.7 \%$ & & $98.1 \%$ \\
\hline 19 & $36.7 \%$ & $37.0 \%$ & & $100.0 \%$ \\
\hline 20 & $39.0 \%$ & $42.0 \%$ & & $97.9 \%$ \\
\hline 21 & $47.2 \%$ & $42.7 \%$ & & $99.8 \%$ \\
\hline 22 & $1.8 \%$ & $42.3 \%$ & & $94.9 \%$ \\
\hline 23 & $5.3 \%$ & $41.6 \%$ & & $0.0 \%$ \\
\hline 24 & $29.0 \%$ & $28.9 \%$ & & $99.8 \%$ \\
\hline Mean & $29.5 \%$ & $35.4 \%$ & $51.8 \%$ & $86.2 \%$ \\
\hline StDv & $16.3 \%$ & $6.6 \%$ & $11.5 \%$ & $27.1 \%$ \\
\hline
\end{tabular}

Source: Own authors.

The Table 2 shows P-values for the tests comparing mean (for normal distributions) and median (for all distributions). P-values marked with * indicate there is not enough evidence to conclude that the means / medians differ at the 0.05 level of significance.

Table 2 - Hypothesis tests and P-value for the first proposition

\begin{tabular}{cccccc}
\hline & \multicolumn{2}{c}{ Compared samples } & Used test & P-value \\
\hline 1 & Timing & $\neq$ & Sampling & Two sample $T$ & $0.106^{*}$ \\
2 & Timing & $<$ & Sampling & Two sample $T$ & $0.053^{*}$ \\
3 & Timing & $<$ & Interview & Two sample $T$ & 0.003 \\
4 & Timing & $<$ & IMS & Paired $T$ & 0.001 \\
5 & Interview & $<$ & IMS & Two sample T & 0.001 \\
6 & Timing & $<$ & IMS & Mann-Whitney & 0.000 \\
7 & Interview & $<$ & IMS & Mann-Whitney & 0.003 \\
8 & \multicolumn{2}{r}{ All samples $\neq$} & & ANOVA & 0.001 \\
9 & \multicolumn{2}{r}{ All samples $\neq$} & & Kruskal Wallis & 0.000 \\
\hline
\end{tabular}

Source: Own authors.

P1. The median of the data collected from different measurement techniques for the added value rate can be considered equal. 
The first proposition can be rejected. There are evidences to declare the medians (and means) among the samples are different at 0.05 level of significance (test number 9). The biggest mean lies on IMS, followed by interview. There is no evidence to declare the timing and sampling means are different at 0.10 level of significance, but there are evidences at 0.05 level. Discussions of the result:

a) About timing and sampling: we can conclude that the observer influence on the observed workman is not bigger for the workman observed by timing. Observer team believes the mean for sampling is bigger than the timing one for AV because workmen that performing idleness activities are often out of the field of view - they try to hide their activities when performing the idleness;

b) About interview and timing: Considering respondents' honesty for answering the interview, we can conclude that the respondents (among them team leaders, who were observed) were not aware of the real added value rate;

c) About IMS and timing: Values on IMS are used for many analyses in the whole company, such costs and prices estimations and cost allocations. But these values are higher than timing ones: it means that there are wastes that are hidden and underestimated to the company. Shingo and Dillon (1989) stated in their book the existence of wastes that are not noticed because they have become accepted as a natural part of daily work. In this study case, the IMS values are an example of wastes not noticed;

d) About IMS and interview: Values as inserted into IMS by workmen (among them the team leaders who were interviewed). We can conclude that workmen were aware that the IMS' values are higher than the values they believed. Actually, there was a goal established by management: having $90 \%$ of the time as productive. Such goal did not help to increase the real added values taxes, but encouraged higher values into IMS. This act can be considered as a counterproductive work behavior;

e) About interview, IMS and timing: It can be concluded that there is no department in that company that know the real values of added value taxes. The results of this article was presented to the company's CEO. This statement was the worried the CEO the most;

\subsection{Differences among wastes}

Table 3 shows the percentage values (concerning the available working day) for all wastes observed (timing). Samples cannot be considered normal. 
Table 3 - Wastes measured per working day

\begin{tabular}{|c|c|c|c|c|c|c|c|}
\hline $\begin{array}{c}\text { Working } \\
\text { days }\end{array}$ & Waiting & Motion & Defects & Processing & Transportation & Idleness & Total \\
\hline 1 & $0.6 \%$ & $0.0 \%$ & $0.0 \%$ & $0.0 \%$ & $0.0 \%$ & $74.9 \%$ & $75.5 \%$ \\
\hline 2 & $3.7 \%$ & $22.1 \%$ & $0.0 \%$ & $19.0 \%$ & $0.0 \%$ & $4.1 \%$ & $49.0 \%$ \\
\hline 3 & $1.8 \%$ & $11.3 \%$ & $1.2 \%$ & $15.0 \%$ & $0.3 \%$ & $13.5 \%$ & $43.0 \%$ \\
\hline 4 & $0.5 \%$ & $3.1 \%$ & $4.8 \%$ & $10.1 \%$ & $0.3 \%$ & $9.6 \%$ & $28.4 \%$ \\
\hline 5 & $2.1 \%$ & $5.6 \%$ & $1.8 \%$ & $14.6 \%$ & $0.9 \%$ & $54.0 \%$ & $79.0 \%$ \\
\hline 6 & $10.0 \%$ & $10.9 \%$ & $1.5 \%$ & $18.3 \%$ & $0.4 \%$ & $11.7 \%$ & $52.9 \%$ \\
\hline 7 & $0.0 \%$ & $2.0 \%$ & $0.0 \%$ & $32.1 \%$ & $0.0 \%$ & $32.1 \%$ & $66.2 \%$ \\
\hline 8 & $2.2 \%$ & $15.7 \%$ & $0.0 \%$ & $34.7 \%$ & $0.3 \%$ & $30.4 \%$ & $83.3 \%$ \\
\hline 9 & $1.0 \%$ & $11.2 \%$ & $1.0 \%$ & $29.6 \%$ & $0.0 \%$ & $9.6 \%$ & $52.3 \%$ \\
\hline 10 & $0.0 \%$ & $0.4 \%$ & $0.0 \%$ & $9.1 \%$ & $0.0 \%$ & $45.5 \%$ & $55.0 \%$ \\
\hline 11 & $0.7 \%$ & $19.3 \%$ & $43.2 \%$ & $17.1 \%$ & $0.0 \%$ & $12.7 \%$ & $93.1 \%$ \\
\hline 12 & $0.3 \%$ & $15.6 \%$ & $9.2 \%$ & $31.8 \%$ & $1.9 \%$ & $14.7 \%$ & $73.4 \%$ \\
\hline 13 & $0.9 \%$ & $12.2 \%$ & $0.0 \%$ & $25.1 \%$ & $2.3 \%$ & $20.4 \%$ & $60.9 \%$ \\
\hline 14 & $1.0 \%$ & $14.5 \%$ & $0.0 \%$ & $15.0 \%$ & $0.0 \%$ & $2.4 \%$ & $32.8 \%$ \\
\hline 15 & $0.2 \%$ & $5.9 \%$ & $0.0 \%$ & $13.9 \%$ & $0.6 \%$ & $5.7 \%$ & $26.3 \%$ \\
\hline 16 & $0.1 \%$ & $7.3 \%$ & $11.0 \%$ & $14.4 \%$ & $0.1 \%$ & $10.4 \%$ & $43.4 \%$ \\
\hline 17 & $3.4 \%$ & $13.5 \%$ & $8.3 \%$ & $20.7 \%$ & $3.7 \%$ & $6.2 \%$ & $55.8 \%$ \\
\hline 18 & $0.7 \%$ & $9.5 \%$ & $0.3 \%$ & $12.3 \%$ & $0.0 \%$ & $32.1 \%$ & $54.9 \%$ \\
\hline 19 & $5.1 \%$ & $10.8 \%$ & $0.1 \%$ & $24.0 \%$ & $0.3 \%$ & $11.9 \%$ & $52.3 \%$ \\
\hline 20 & $0.1 \%$ & $11.4 \%$ & $7.2 \%$ & $21.0 \%$ & $0.0 \%$ & $10.3 \%$ & $50.0 \%$ \\
\hline 21 & $0.3 \%$ & $9.1 \%$ & $7.1 \%$ & $12.2 \%$ & $0.1 \%$ & $10.3 \%$ & $39.1 \%$ \\
\hline 22 & $1.3 \%$ & $6.0 \%$ & $20.6 \%$ & $16.8 \%$ & $0.5 \%$ & $43.0 \%$ & $88.0 \%$ \\
\hline 23 & $4.2 \%$ & $9.0 \%$ & $26.2 \%$ & $18.9 \%$ & $0.0 \%$ & $24.3 \%$ & $82.7 \%$ \\
\hline 24 & $2.6 \%$ & $8.7 \%$ & $19.6 \%$ & $24.8 \%$ & $0.0 \%$ & $4.6 \%$ & $60.3 \%$ \\
\hline Mean & $1.8 \%$ & $9.8 \%$ & $6.8 \%$ & $18.8 \%$ & $0.5 \%$ & $20.6 \%$ & $58.2 \%$ \\
\hline StDv & $2.3 \%$ & $5.5 \%$ & $10.8 \%$ & $8.2 \%$ & $0.9 \%$ & $18.3 \%$ & $18.7 \%$ \\
\hline
\end{tabular}

Source: Own authors.

For the second proposition there were three tests comparing median. In the first one, all compared samples were different and the test used was the Kruskal Wallis. The P-value for the first test was 0.000. In the second test, Idleness was different from Processing and the test used was the Mann-Whitney. The P-value for the second test was $0.307^{*}$. Finally, the third comparison was Idleness greater than Motion and the test used was the Mann-Whitney. The P-value for the third test was 0.019. P-values marked with * indicate there is not enough evidence to conclude that the medians differ at the 0.05 level of significance.

P2. The median of each kind of wastes can be considered equal.

The second proposition can be rejected. Performing all tests at 0.05 level of significance, there are evidences to declare the medians among the samples are different (test number 1). The biggest deterministic median lies on Idleness, followed by Processing, but there is no enough evidence to declare their medians are different in a stochastic comparison. There are evidences to declare the medians of idleness is higher than motion, that presents the third biggest deterministic mean. The 
biggest deterministic mean were found respectively in: idleness (20.6\%), processing (18.8\%), motion (9.8\%), defects (6.8), waiting (1.8) and transportation (0.5\%).

Considering only the common lean wastes that was measured (processing, motion, defects, waiting and transportation), the biggest waste found in this case study (processing) is the less focused waste in lean articles according to Jasti and Kodali (2014), but corresponds to the main wastes that are expected to be removed by applying Lean according to Indian respondents (Jasti \& Kodali, 2016).

\subsection{Variation of added value along the working day}

Appendix A shows the percentage means of added value collected every 10 minutes during the working day (62 values per working day) with the sampling method. The time of day when the observation was made was called by " $\mathrm{t}$ ", it is in decimal. The column lunch (L) shows information about lunch time: Times before lunch $(L=1)$, times during the period when workmen could have lunch $(L=-1)$ and times after lunch $(L=2)$. The time for lunch was not measured. The working day was shared into 9 groups (G) for facilitating comparisons. Samples inside groups cannot be considered normal.

The Table 4 shows P-values for the tests comparing median (Kruskal Wallis test). P-values marked with * indicate there is not enough evidence to conclude that the medians differ at the 0.05 level of significance.

Table 4 - Hypothesis tests and P-value for the third proposition

\begin{tabular}{ccccc}
\hline Test $N$. - & \multicolumn{3}{c}{ Compared groups' samples } & P-value \\
\hline 1 & \multicolumn{3}{c}{ All samples $\neq$} & 0.000 \\
2 & $1,2,3$ e 4 & $>$ & $6,7,8$ e 9 & 0.001 \\
3 & 3 & $>$ & 1,2 e 4 & 0.000 \\
4 & 3 & $>$ & $1,2,4,6,7,8$ e 9 & 0.000 \\
5 & 7 & $>$ & 6,8 e 9 & 0.000 \\
6 & 7 & $>$ & $1,2,3,4,6,8$ e 9 & $0.059 *$ \\
7 & $1,4,6$ e 9 & $<$ & $2,3,7$ e 8 & 0.000
\end{tabular}

Source: Own authors.

P3. The added value rates are constant along the day.

The third proposition can be rejected (test number 1). Performing all tests at 0.05 level of significance, there are evidences to declare the medians among the groups of time of day are different. The median of the morning period (groups 1, 2, 3 and 4) is bigger than the afternoon (group 
$6,7,8$ and 9). The median of the end of the morning (group 3) has the biggest value in the working day and the median of the beginning of the afternoon (group 7) has the biggest value for the afternoon period. The median of ends and starts of periods (groups 1, 4, 6 and 9) has the smallest value.

The difference between the variation of added value rate of this case study and the theoretical variation of the readiness for work during a continuous working day with intermediary pauses according to Grandjean and Kroemer (1997) lies on the early morning. For Grandjean and Kroemer (1997), the beginning of the morning has the biggest values for readiness for work. In this case study, considering a big readiness for work in this period, the added value was not such high. An interpretation for this difference may be idleness activities in this period of the day with 'good morning talks" among workmen and also preparations for work (tools, toolings, materials, documents).

Equation I presents the regression for performance during the working day found by Spencer (1987) for his case study. Performance is calculated from the time of day (T) and the time since wake up (t), both in hours. The Figure 2 shows the graphic of his regression applied in the context of this case study: the working day started at 7h30 and it was considered that workmen woke up at $6 \mathrm{~h}$. The values for performance are in percentage regarding the smallest and the biggest found values for DSST in this period.

$\operatorname{DSST}(T, t)=233,3+1,54 t-0,304 t^{2}+0,0108 t^{3}+4,97 \cos \left(\frac{2 \pi(T-17,05)}{24}\right)$

Figure 2 - Perform expected according to Spencer (1987) regression during the time of the day (T)

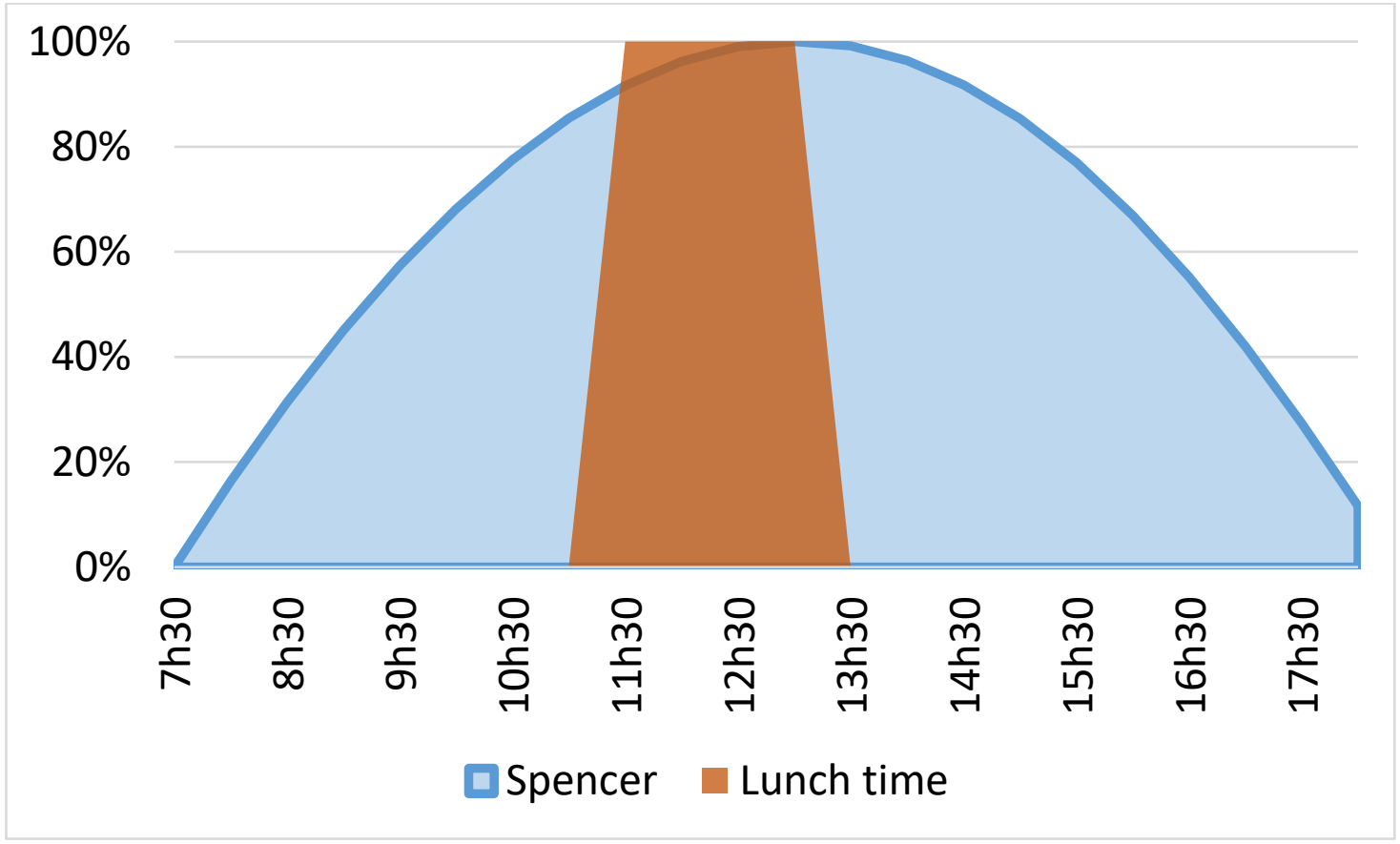

Source: Own authors. 
The difference between the variation of added value rate of this case study and the variation of performance according to Spencer (1987) lies on two periods. The first period is the lunch time (marked in orange in Figure 2). Spencer did not consider this period when the added value rates are zero. The second period is the beginning of the afternoon: according to Spencer (1987), this period should have the biggest values, but this case study found the biggest values before the lunch time. An interpretation for these differences may be the low fit of Spencer's regression and also because Spencer got the regression for that case study and it cannot be automatically generalized for any study.

In order to obtain a regression that describes the added value as a function of the time of the day and lunch time, a multiple regression was performed using the Ordinary Least Squares method and the data available in Appendix A. However, the fit obtained was low $\left(R^{2}=39.14 \%\right)$. Thus, interactions between the terms were performed and the value of the fit was satisfactory $\left(R^{2}=\right.$ 77.34\%). However, the terms presented high variance inflation factor due to the high collinearity. According to Bastien, Vinzi and Tenenhaus (2005) and Tenenhaus, Vinzi, Chatelin and Lauro (2005), when there is a high correlation among factors, Partial Least Squares regression must be preferred. The regression can be seen in equation II. The AV values are calculated from the time of the day $(t)$ and I the time for lunch (I). It was used a model with 7 principal components because it has a higher $\mathrm{R}^{2}$ predicted $(71.45 \%)$ and is therefore considered as an "optimal model". This model explains $100.00 \%$ of the variance of its predictors and presents a fit (R squared) of $79.9 \%$, considered satisfactory value. The P-value value for the variance analysis of the optimal model was 0.000 (which is lower than the alpha value of 0.05 ), which means that the 7-component model is significant. The residuals can be considered normal

$$
\begin{gathered}
\mathrm{AV}(\%)=-21,8922+7,4607 * \mathrm{t}-0,9159 * \mathrm{t}^{2}+0,0489 * \mathrm{t}^{3}-0,0010 * \mathrm{t}^{4}-0,2358 * \mathrm{l} \\
-0,0145 * \mathrm{l}^{2}-0,0170 * \mathrm{l}^{3}-0,029 * \mathrm{l}^{4} \quad+0,0347 * \mathrm{t} * \mathrm{l}
\end{gathered}
$$

\subsection{Workmen's profiles and their impacts on idleness}

The questions and possible answers for the interview with the observed workman were: Age (in years); Experience in the company (in years); Marriage: if the workman is married (or in stable relationship) or single (widower or divorced) (-1 single; 1 married); Children: if the workman has at least one child or no children (-1 without; 1 with); Training: if the workman attended a special international training provided by the company(-1 without; 1 with); Origin: from the state where the company is located or outside (-1 outside; 1 local). Table 5 shows the answers obtained and the idleness (called by 'idle') concerned for each workman. 
Table 5 - Answers of the interview and correspondent idleness values

\begin{tabular}{cccccccc}
\hline Workman & Iddle & Age & Experience & Marriage & Children & Training: & Origin \\
\hline 1 & $74.9 \%$ & 34 & 3.0 & -1 & -1 & 1 & 1 \\
2 & $4.1 \%$ & 33 & 2.0 & 1 & -1 & -1 & -1 \\
3 & $13.5 \%$ & 32 & 0.7 & -1 & 1 & -1 & 1 \\
4 & $9.6 \%$ & 39 & 0.6 & -1 & 1 & -1 & -1 \\
5 & $54.0 \%$ & 29 & 4.0 & -1 & -1 & -1 & -1 \\
6 & $11.7 \%$ & 38 & 0.6 & -1 & 1 & -1 & -1 \\
7 & $32.1 \%$ & 32 & 1.0 & -1 & 1 & -1 & -1 \\
8 & $30.4 \%$ & 34 & 5.8 & -1 & 1 & 1 & -1 \\
9 & $9.6 \%$ & 28 & 2.5 & -1 & 1 & 1 & 1 \\
10 & $45.5 \%$ & 34 & 0.7 & -1 & 1 & -1 & -1 \\
11 & $12.7 \%$ & 37 & 0.8 & -1 & 1 & -1 & -1 \\
12 & $14.7 \%$ & 40 & 0.8 & -1 & 1 & -1 & 1 \\
13 & $20.4 \%$ & 30 & 0.8 & -1 & 1 & -1 & 1 \\
14 & $2.4 \%$ & 31 & 1.0 & -1 & 1 & -1 & 1 \\
15 & $5.7 \%$ & 28 & 0.9 & 1 & 1 & -1 & 1 \\
16 & $10.4 \%$ & 43 & 0.8 & -1 & 1 & -1 & -1 \\
17 & $6.2 \%$ & 31 & 1.1 & 1 & -1 & -1 & -1 \\
18 & $32.1 \%$ & 31 & 2.0 & -1 & 1 & 1 & -1 \\
19 & $11.9 \%$ & 43 & 0.8 & -1 & 1 & -1 & -1 \\
20 & $10.3 \%$ & 24 & 0.6 & 1 & -1 & -1 & 1 \\
21 & $10.3 \%$ & 48 & 1.3 & -1 & 1 & -1 & 1 \\
22 & $43.0 \%$ & 42 & 1.7 & -1 & 1 & -1 & -1 \\
23 & $24.3 \%$ & 31 & 2.5 & -1 & 1 & 1 & -1 \\
24 & $4.6 \%$ & 43 & 2.5 & -1 & 1 & 1 & -1 \\
\hline
\end{tabular}

Source: Own authors.

In order to obtain a regression that relates the idleness with the answers collected in the interview, a multiple regression was performed using the Ordinary Least Squares method and the data available in Appendix A. However, the fit obtained was low $\left(R^{2}=36.50 \%\right)$. Thus, interactions between the terms were performed and the value of the fit was satisfactory $\left(R^{2}=77.75 \%\right)$. However, the terms presented high variance inflation factor due to the high collinearity. According to Bastien et al. (2005) and Tenenhaus et al. (2005), when there is a high correlation among factors, Partial Least Squares regression must be preferred. The regression can be seen in equation III. It was used a model with 3 principal components because it has a higher $R^{2}$ predicted (17.3\%) and is therefore considered as an "optimal model". This model explains $50.8 \%$ of the variance of its predictors and presents a fit (R squared) of $72.2 \%$, considered satisfactory value. The P-value value for the variance analysis of the optimal model was 0.000 (which is lower than the alpha value of 0.05 ), which means that the 3component model is significant. The residuals can be considered normal

$$
\begin{array}{rl}
\text { Idlle }=0.3085 & 49-0.002541 * A g+0.012718 * E x-0.048176 * M a-0,024322 \\
& * C h+0.013749 * T r+0.000107 * O r+0.000317 * A g * E x \\
& +0.000337 * A g * T r-0.001177 * A g * M a-0.000875 * A g * C h \\
& +0.000207 * I d * O r+0.000697 * E x * T r-0.021182 * E x * M a \\
& -0.017799 * E x * C h+0.004808 * E x * O r+0.016923 * T r * M a \\
& -0.034133 * T r * C h+0.022353 * T r * O r+0.066682 * M a * C h \\
& +0.007878 * M a * \text { Or }-0.037615 * C h * O r-0.000041 * A g * A g \\
& +0.00124 * E x * E x
\end{array}
$$


In order to know which free predictors that impact the idleness the most, the Monte Carlo simulation with 100,000 trials and the sensitivity analyses were performed from the equation III. More information about Monte Carlo and sensitivity analysis are provided by Rubinstein and Kroese (2016). The inputs values were considered as one can see right above the Table 5: negative values for idleness

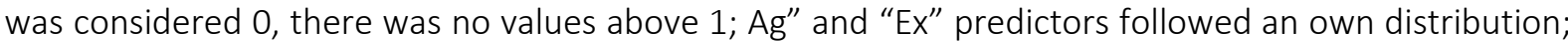
"Ma", "Ch", "Tr" and "Or" predictors followed the Bernoulli discrete distribution, with binary values, and terms of interaction were taken into account as function of their free predictors. The mean and standard deviation obtained with the Monte Carlo simulation for idleness values were 0.27 and 0.13 respectively. The sensitivity analyses for idleness shows the respective values: Married $-46.1 \%$; Children -31.8\%; Local -10.7\%; Experience 6.4\%; Training -2.9\%; Age -2.2\%.

P4: There is a defined workmen's profile that impact the idleness the most.

The fourth proposition cannot be rejected. Among the items analyzed in the interview, the two items that impact the most for a smaller idleness are: being married $(+1)$ and having children $(+1)$. Other items are respectively: being originally from the same state where the company is located in $(+1)$, having less experience at the company $(-1)$, having had training $(+1)$ and being older $(+1)$. Company's actions for decrease idleness have to be target to single and without children workmen.

\section{Final discussions and conclusion}

This paper fulfills a gap in Lean literature by performing a case study focused on wastes and performance measurement and organization behaviors in an aeronautical manufacture environment. This empirical study measured the working day of employees using several techniques of data collection and observation.

The paper also contributes to the operations management literature by merging Lean interventions and counterproductive work behavior (CWB) activities. So, the idleness was defined as the waste concerning CWB activities. Hypothesis tests for analyzing added value rates and wastes, specially the idleness, were proposed and developed.

The first hypothesis proposed in this research concerned differences among collecting data techniques. We compared the results with Shingo and Dillon (1989) statement: the existence of wastes at Toyota that are not noticed because they have become accepted as a natural part of daily work. Results showed differences concerning added value taxes measures by each technique. Data from the integrated management system (software used to share information and data among departments) are over estimated. Actually, integrated management systems can hide real added values as users do not insert consciously on them real wastes values, and this is also an example of CWB. In this context, if wastes are not reported and countermeasures are not taken, companies can 
accept wastes as natural part of daily work. Also, from observers' commentaries, we can conclude that idleness activities can be difficult to be perceived. Due to that, we can expect idleness may be barely reported or noticed to higher management. Also, the goals established by high management could have encouraged workmen to insert false values of added value into IMS. We conclude that there were no department at the company that knew the real add values.

From the analyses made by Jasti and Kodali $(2014,2016)$, we can conclude that the wastes mentioned the most in Lean articles cannot correspond to the wastes expected to be removed by implementing Lean. The second hypothesis proposed concerned differences among wastes and compared them to Jasti and Kodali $(2014,2016)$ sequences of wastes. Results showed the idleness as the biggest waste in this case study. Although identified by Taylor one century ago, CWBs activities were ignored in Lean literature as a waste.

The third hypothesis proposed concerned the variation of added value rates along the working day. Results from this case study were compared with Spencer's (1987) and Grandjean and Kroemer's (1997) similar results. Spencer's research did not consider the effect of feeding on performance level. Grandjean and Kroemer's proposition may not correspond to added value rates because wastes, especially the idleness, can decrease the value of expected performance along the day. The period of the day presented biggest added value in this case study was the morning period, especially before lunch.

The fourth proposed hypothesis concerned the workmen's profiles and their impacts on idleness. Married workmen and that ones that have children had smaller idleness rates. But these results cannot be generalized.

Since the limitations of this paper stand on being a single case study and therefore its results cannot be globally validated, it is recommended for future papers, replicates of the procedure used in this paper in different types of companies for comparison and the external validation of the results. For this, a framework of followed detailed steps was furnished. We expected results concerning found values and hypothesis can be compared with replicates. The most important implication of this research is the recommendation the use of idleness as waste in Lean analyses because the impact of ignoring it can be seen as accepting wastes as natural in daily work.

\section{References}

Bastien, P., Vinzi, V. E., \& Tenenhaus, M. (2005). PLS generalised linear regression. Computational Statistics \& data analysis, 48(1), 17-46. https://doi.org/10.1016/j.csda.2004.02.005.

Bennett, R. J., \& Robinson, S. L. (2000). Development of a measure of workplace deviance. Journal of Applied Psychology, 85(3), 349-360. https://doi.org/10.1037/0021-9010.85.3.349. 
Bhamu, J., \& Sangwan, K. S. (2014). Lean manufacturing: literature review and research issues. International Journal of Operations \& Production Management, 34(7), 876-940. https://doi.org/10.1108/IJOPM-08-2012-0315.

Bollinger, T., Leutz, A., Leliavski, A., Skrum, L., Kovac, J., Bonacina, L., Benedict, C., Lange, T., Westermann, J., Oster, H., \& Solbach, W. (2011). Circadian clocks in mouse and human CD4+ T cells. PloS one, 6(12), e29801. https://doi.org/10.1371/journal.pone.0029801.

Broeck, A. van den, Sulea, C., Vander Elst, T., Fischmann, G., Iliescu, D., \& Witte, H. de (2014). The mediating role of psychological needs in the relation between qualitative job insecurity and counterproductive work behavior. Career Development International, 19(5), 526-547. https://doi.org/10.1108/CDI-05-2013-0063.

Desirée, H. van dun, Hicks, J. N., \& Wilderom, C. P. (2017). Values and behaviors of effective lean managers: mixed-methods exploratory research. European management journal, 35(2), 174-186. https://doi.org/10.1016/j.emj.2016.05.001.

Fox, S., Spector, P. E., Goh, A., Bruursema, K., \& Kessler, S. R. (2012). The deviant citizen: measuring potential positive relations between counterproductive work behaviour and organizational citizenship behaviour. Journal of Occupational and Organizational Psychology, 85(1), 199-220. https://doi.org/10.1111/j.2044-8325.2011.02032.x.

Fox, S., \& Spector, P. E. (1999). A model of work frustration-aggression. Journal of organizational behavior, 20(6), 915-931. https://doi.org/10.1002/(SICI)1099-1379(199911)20:6<915::AIDJOB918>3.0.CO;2-6.

Grandjean, E., \& Kroemer, K. H. E. (1997). Fitting the task to the human: a textbook of occupational ergonomics. 5th ed. Boca Raton, FL: CRC press.

Haque, B., \& Moore, M. J. (2004). Measures of performance for lean product introduction in the aerospace industry. Proceedings of the Institution of Mechanical Engineers Part B: Journal of Engineering Manufacture, 218 (10), 1387-1398. https://doi.org/10.1243/0954405042323496.

Hines, P., Rich, N., Bicheno, J., Brunt, D., Taylor, D., Butterworth, C., \& Sullivan, J. (1998). Value stream management. The International Journal of Logistics Management, 9(1), 25-42. https://doi.org/10.1108/09574099810805726.

Hollinger, R. C. (1986). Acts against the workplace: social bonding and employee deviance. Deviant Behavior, 7(1), 53-75. https://doi.org/10.1080/01639625.1986.9967695.

Jasti, N. V. K., \& Kodali, R. (2014). A literature review of empirical research methodology in lean manufacturing. International Journal of Operations and Production Management, 34(8), 1080-1122. https://doi.org/10.1108/IJOPM-04-2012-0169.

Jasti, N. V. K., \& Kodali, R. (2016.) An empirical study for implementation of lean principles in Indian manufacturing industry. Benchmarking: An International Journal, 23(1), 183-207. https://doi.org/10.1108/BIJ-11-2013-0101.

Martinez-Nicolas, A., Madrid, J.A., \& Rol, M. A. (2014). Day-night contrast as source of health for the human circadian system. Chronobiology international, 31(3), 382-93. https://doi.org/10.3109/07420528.2013.861845.

Ohno, T. (1988). Toyota production system: beyond large-scale production. Portland, OR: Productivity Press. 
Robinson, S. L., \& Bennett, R. J. (1995). A typology of deviant workplace behaviors: a multidimensional scaling study. Academy of Management Journal, 38(2), 555-572. https://doi.org/10.5465/256693.

Roth, A. V., (2007). Applications of empirical science in manufacturing and service operations. Manufacturing \& Service Operations Management, 9(4), 353-367. https://doi.org/10.1287/msom.1070.0197.

Rubinstein, R. Y., \& Kroese, D. P. (2016). Simulation and the Monte Carlo method. Hoboken, NJ: John Wiley \& Sons.

Samuel, D., Found, P., \& Williams, S. J. (2015). How did the publication of the book The Machine That Changed The World change management thinking? Exploring 25 years of lean literature. International Journal of Operations and Production Management, 35(10), 1386-1407. https://doi.org/10.1108/IJOPM-12-2013-0555.

Shah, R., \& Ward, P. T. (2007). Defining and developing measures of lean production. Journal of Operations Management, 25(4), 785-805. https://doi.org/10.1016/j.jom.2007.01.019.

Shingo, S., \& Dillon, A. P. (1989). A study of the Toyota production system: from an Industrial Engineering viewpoint. New York, NY: Productivity Press.

Skarlicki, D. P., \& Folger, R. (1997). Retaliation in the workplace: the roles of distributive, procedural, and interactional justice. Journal of Applied Psychology, 82(3), 434-443.

https://doi.org/10.1037/0021-9010.82.3.434.

Spector, P. E. (1975). Relationships of organizational frustration with reported behavioral reactions of employees. Journal of Applied Psychology, 60(5), 227-234. https://doi.org/10.1037/h0077157.

Spector, P. E., \& Fox, S. (2010). Counterproductive work behavior and organisational citizenship behavior: are they opposite forms of active behavior? Applied Psychology, 59(1), 21-39. https://doi.org/10.1111/j.1464-0597.2009.00414.x.

Spencer, M. B. (1987). The influence of irregularity of rest and activity on performance: a model based on time since sleep and time of day. Ergonomics, 30(9), 1275-1286.

https://doi.org/10.1080/00140138708966022.

Taylor, F. W. (2013). The principles of scientific management. Scotts Valley, CA: CreateSpace Independent Publishing Platform.

Tenenhaus, M., Vinzi, V. E., Chatelin, Y. M., \& Lauro, C. (2005). PLS path modeling. Computational statistics \& data analysis, 48(1), 159-205. https://doi.org/10.1016/j.csda.2004.03.005.

Tyagi, S., Choudhary, A., Cai, X., \& Yang, K. (2015). Value stream mapping to reduce the lead-time of a product development process. International Journal of Production Economics, 160, 202-212. https://doi.org/10.1016/j.ijpe.2014.11.002.

Voss, C., Tsikriktsis, N., \& Frohlich, M. (2002). Case research in operations management. International Journal of Operations and Production Management, 22(2), 195-219.

https://doi.org/10.1108/01443570210414329.

Whelpley, C. E., \& McDaniel, M. A. (2016). Self-esteem and counterproductive work behaviors: a systematic review. Journal of Managerial Psychology, 31(4), 850-863. https://doi.org/10.1108/JMP01-2014-0008. 
Carvalho Neto, L., Leal, F., \& Oliveira, M. S. de (2020, out./dez.). Proposal and application of a procedure for analysis of idleness and wastes in an aircraft company

Womack, J. P., \& Jones, D. T. (2003). Lean thinking: banish waste and create wealth in your corporation, revised and updated II. New York, NY: Productivity Press.

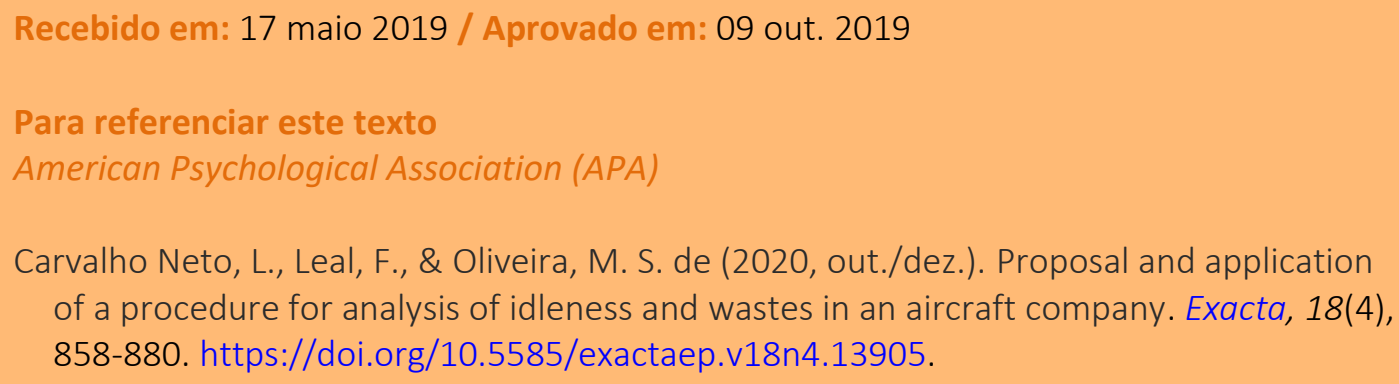

\begin{tabular}{|c|c|c|c|}
\hline \multicolumn{4}{|c|}{ Appendix A } \\
\hline Time $(\mathrm{t})$ & Lunch (L) & Group (G) & AV \\
\hline 7.50 & 1 & \multirow[t]{3}{*}{1} & $4.5 \%$ \\
\hline 7.67 & 1 & & $17.9 \%$ \\
\hline 7.83 & 1 & & $26.5 \%$ \\
\hline 8.00 & 1 & \multirow[t]{12}{*}{2} & $27.2 \%$ \\
\hline 8.17 & 1 & & $35.2 \%$ \\
\hline 8.33 & 1 & & $33.9 \%$ \\
\hline 8.50 & 1 & & $38.9 \%$ \\
\hline 8.67 & 1 & & $32.7 \%$ \\
\hline 8.83 & 1 & & $34.4 \%$ \\
\hline 9.00 & 1 & & $38.9 \%$ \\
\hline 9.17 & 1 & & $33.3 \%$ \\
\hline 9.33 & 1 & & $42.1 \%$ \\
\hline 9.50 & 1 & & $39.4 \%$ \\
\hline 9.67 & 1 & & $38.7 \%$ \\
\hline 9.83 & 1 & & $43.0 \%$ \\
\hline 10.00 & 1 & \multirow[t]{9}{*}{3} & $48.4 \%$ \\
\hline 10.17 & 1 & & $44.2 \%$ \\
\hline 10.33 & 1 & & $40.3 \%$ \\
\hline 10.50 & 1 & & $47.0 \%$ \\
\hline 10.67 & 1 & & $51.8 \%$ \\
\hline 10.83 & 1 & & $48.8 \%$ \\
\hline 11.00 & 1 & & $45.5 \%$ \\
\hline 11.17 & 1 & & $46.9 \%$ \\
\hline 11.33 & 1 & & $46.4 \%$ \\
\hline 11.50 & 1 & \multirow[t]{2}{*}{4} & $25.4 \%$ \\
\hline 11.67 & 1 & & $11.1 \%$ \\
\hline 11.83 & -1 & \multirow[t]{5}{*}{5} & $0.0 \%$ \\
\hline 12.00 & -1 & & $0.0 \%$ \\
\hline 12.17 & -1 & & $0.0 \%$ \\
\hline 12.33 & -1 & & $0.0 \%$ \\
\hline 12.50 & -1 & & $0.0 \%$ \\
\hline 12.67 & -1 & 6 & $25.0 \%$ \\
\hline
\end{tabular}


- -HEr Carvalho Neto, L., Leal, F., \& Oliveira, M. S. de (2020, out./dez.). Proposal and application of a procedure for analysis of idleness and wastes in an aircraft company

\begin{tabular}{|c|c|c|c|}
\hline 12.83 & -1 & & $20.0 \%$ \\
\hline 13.00 & -1 & & $28.2 \%$ \\
\hline 13.17 & 2 & \multirow[t]{12}{*}{7} & $34.8 \%$ \\
\hline 13.33 & 2 & & $41.3 \%$ \\
\hline 13.50 & 2 & & $42.1 \%$ \\
\hline 13.67 & 2 & & $39.4 \%$ \\
\hline 13.83 & 2 & & $43.1 \%$ \\
\hline 14.00 & 2 & & $36.0 \%$ \\
\hline 14.17 & 2 & & $35.5 \%$ \\
\hline 14.33 & 2 & & $38.3 \%$ \\
\hline 14.50 & 2 & & $38.7 \%$ \\
\hline 14.67 & 2 & & $35.5 \%$ \\
\hline 14.83 & 2 & & $34.1 \%$ \\
\hline 15.00 & 2 & & $39.0 \%$ \\
\hline 15.17 & 2 & \multirow[t]{13}{*}{8} & $34.0 \%$ \\
\hline 15.33 & 2 & & $34.0 \%$ \\
\hline 15.50 & 2 & & $33.7 \%$ \\
\hline 15.67 & 2 & & $34.8 \%$ \\
\hline 15.83 & 2 & & $32.6 \%$ \\
\hline 16.00 & 2 & & $34.9 \%$ \\
\hline 16.17 & 2 & & $32.0 \%$ \\
\hline 16.33 & 2 & & $33.1 \%$ \\
\hline 16.50 & 2 & & $34.2 \%$ \\
\hline 16.67 & 2 & & $35.1 \%$ \\
\hline 16.83 & 2 & & $35.5 \%$ \\
\hline 17.00 & 2 & & $34.2 \%$ \\
\hline 17.17 & 2 & & $24.5 \%$ \\
\hline 17.33 & 2 & \multirow[t]{3}{*}{9} & $15.3 \%$ \\
\hline 17.50 & 2 & & $4.8 \%$ \\
\hline 17.67 & 2 & & $3.0 \%$ \\
\hline
\end{tabular}

